\title{
Potential of Oil Palm Frond Residues in Combination with S-Metolachlor for the Inhibition of Selected Herbicide-Resistant Biotypes of Goosegrass Emergence and Seedling Growth
}

(Potensi Residu Minyak Kelapa Sawit dengan S-Metolachlor untuk Perencatan Herbisid Terpilih - Rintangan Biotip daripada Kemunculan Rumput Sambau dan Pertumbuhan Anak Benih)

Chuah Tse SENG*, Lim Win Kent \& ISMAIL B.S.

ABSTRACT

Heavy reliance on herbicides for goosegrass (Eleusine indica Gaertn.) control has led to the development of paraquat, glufosinate, fluazifop and/or glyphosate resistance in goosegrass. This study aimed to evaluate the efficacy of preemergence herbicide, S-metolachlor-treated oil palm frond powder on inhibition of resistant biotypes of goosegrass under glasshouse and field conditions. The oil palm frond (OPF) powder was treated with S-metolachlor at its suboptimal rate and applied as mulch. The herbicide-resistant goosegrass plants were found to be more inhibited when treated

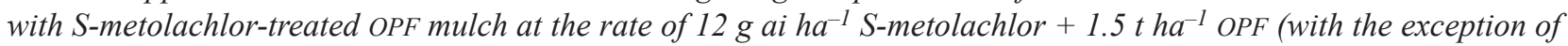
the glufosinate-resistant googegrass biotype in the sandy loam soil) compared to the growth of the resistant biotypes in silty loam soil under glasshouse conditions. Field experiments in an ambarella (Spondias dulcis L.) farm further showed that OPF -treated with S-metolachlor mulch at the rate of $32.0 \mathrm{~g}$ ai ha ${ }^{-1} \mathrm{~S}$-metolachlor +4.0 th $\mathrm{a}^{-1}$ OPF provided great suppression of glyphosate-resistant biotypes of goosegrass with more than $85 \%$ reduction of weed density and biomass, respectively. These results suggested that the residue of OPF have the potential to reduce the application rate of S-metolachor without compromising on the excellent control obtained in combating these herbicide-resistant biotypes of goosegrass.

Keywords: Eleusine indica; herbicide resistance; pre-emergence; S-metolachlor; weed management

\section{ABSTRAK}

Kebergantungan yang tinggi terhadap herbisid untuk mengawal rumput sambau (Eleusine indica Gaertn.) telah mewujudkan sifat kerintangan rumput sambau terhadap paraquat, glufosinat, fluazifop dan/atau glifosat. Kajian ini bertujuan untuk menilai keberkesanan, direaksi serbuk pelepah kelapa sawit yang diperlakukan dengan herbisid pracambah S-metolachlor ke atas biotip rumput sambau rintang dalam rumah hijau dan lapangan. Serbuk pelepah kelapa sawit (OPF) yang telah diperlaku dengan S-metolachlor pada kadar suboptimum dan digunakan sebagai sungkupan. Rumput sambau rintang herbisid didapati lebih terencat apabila dirawat dengan S-metolachlor melalui sungkupan OPF pada kadar $12 \mathrm{~g}$ ai ha- ${ }^{-1}$ S-metolachlor $+1.5 \mathrm{th} \mathrm{a}^{-1}$ OPF (kecuali biotip rumput sambau rintang glufosinate dalam tanah loam berpasir) berbanding pertumbuhan biotip rintang di dalam tanah liat berkelodak di bawah keadaan rumah hijau. Uji kaji di lapangan dalam ladang tanaman ambarella (Spondias dulcis L.) juga menunjukkan bahawa OPF diperlaku dengan S-metolachlor pada kadar sungkupan $32.0 \mathrm{~g}$ ai ha $\mathrm{a}^{-1}$ dan S-metolachlor +4.0 t ha ${ }^{-1}$ OPF menyebabkan perencatan yang besar terhadap glifosat tahan biotip rumput sambau rintang terhadap glifosat dengan pengurangan masing-masing melebihi $85 \%$ daripada kepadatan rumpai dan biojisim. Keputusan ini menunjukkan bahawa sisa OPF mempunyai potensi untuk mengurangkan kadar aplikasi S-metolachor tanpa menjejaskan kesan kawalan dalam menangani biotip rumput sambau rintang herbisid.

Kata kunci: Eleusine indica; herbisid pra-cambah; kerintangan herbisid; pengurusan rumpai; S-metolachlor

\section{INTRODUCTION}

Goosegrass (Eleusine indica Gaertn) is one of the most troublesome of the annual grassy weed in the world (Holm et al. 1977). It seriously affects the production of 46 different crop species in over 60 countries (Stecker 2010). It has been documented as one of the most difficult to control among the turfgrass weeds in the tropical and subtropical regions because the seed heads are typically present throughout the year (Wiecko 2000). Besides, it is also tolerant to a wide range of salt stress, $\mathrm{pH}$ (Chauhan \& Johnson 2008) and water stress (Ismail et al. 2003, 2002) which results in the plant's ability to survive under various unfavorable conditions. Goosegrass seeds buried at $20 \mathrm{~cm}$ depth still had $79 \%$ viability after two years (Chuah et al. 2004a). A recent study by Ma et al. (2015) 
demonstrated that goosegrass at a density of 4 plants $\mathrm{m}^{-1}$ per row significantly reduced cotton yields by 20 to $27 \%$. Rizzardi and Wandscheer (2014) documented that E. indica was more competitive than Sorghum sudanense in mixed infestations with corn but in contrast $S$. sudanense was more competitive than $E$. indica, in mixed infestations with soybean.

Herbicide usage has increased in both zero tillage and conventional systems because it remains the most common strategy to practice due to its convenience, time/ labour saving and for generally being the most effective method of weed control. Eleusine indica can be controlled by various groups of herbicides namely metribuzin, trifloxysulfuron and pendimethalin (Odero et al. 2013). However, the application of a single type of herbicide over a long period of time will facilitate the development of herbicide resistance. For example, multiple resistance in E. indica has been reported previously and this encompasses simultaneous resistance to two different herbicides (Chuah et al. 2010). In the year 2014, an experiment was conducted to evaluate the possibility of multiple resistances to a range of herbicides with four different modes of action (Jalaludin et al. 2015). The results confirmed that the goosegrass biotype was the first case whereby the development of multiple resistance across the three non-selective herbicides, namely glyphosate, glufosinate and paraquat. Moreover, the same population also showed target-site resistance to ACCase-inhibiting herbicides, possibly due to the Trp-2027-Cys mutation (Jalaludin et al. 2015). Various combinations of herbicides have been introduced to provide better and longer term control of goosegrass (Chuah et al. 2004b; Clewis et al. 2008; Everman et al. 2009). Nevertheless, a mixture of glyphosate and glufosinate is not recommended for goosegrass due to antagonistic activity (Bethke 2013; Chuah et al. 2008).

Metolachlor, a pre-emergence and systemic herbicide, comprises equal proportions of R-isomers and S-isomers, with $\mathrm{S}$-isomers providing most of the herbicidal activity. An enantiomerically enriched form ( $>80 \%$ S-isomers) of metolachlor, called S-metolachlor has been developed to reduce the applicationand chemical load to the environment, while increasing the biological activity of the herbicide (Blaser \& Spindler 1997). S-metolachlor can be used to control broadleafed weeds, but it is mainly used to control annual grassy weeds such as foxtail, crabgrass, barnyardgrass and red rice. S-metolachlor is currently registered and used for over 70 crops in vegetable farms and orchards worldwide (O'Connell et al. 1998). Although $\mathrm{S}$-metolachlor was introduced 20 years ago, there has been no reported cases of resistance arising in the weeds as a consequence of widespread use worldwide (Heap 2017).

In general, organic mulches may provide good suppression of annual grassy weeds, but not for perennial weeds (Wilen 1999). Teasdale and Mohler (2000) have quantified the relationship between weed emergence and physical characteristics of mulch for various dry mulch applications at different rates. It is stated that weed suppression is due to the obstructing elements making up the mulch (which physically impede seedling growth) and thus limit light penetration (Teasdale \& Mohler 1993). However, some of the research findings have proved that the residues of crops such as rye, sunflower, wheat and barley not only provide physical obstruction, but also release allelochemicals that suppress weed growth. Generally, the effect of crop residues for weed management declines after four to six weeks due to the breakdown of the allelochemicals (Batish et al. 2007). Recently, it has been reported that the oil palm rachis powder reduced emergence and growth of goosegrass seedlings by approximately 20 and $50 \%$ at $4 \mathrm{tha}^{-1}$, respectively, while its extract provided complete inhibition of goosegrass germination at a concentration of as low as $1.0 \%(\mathrm{w} / \mathrm{v})$ (Chuah \& Lim 2015). In addition, Dilipkumar et al. (2017) have showed the potential use of oil palm frond mulch treated with imazethapyr for weed control in Malaysian coconut plantation. However, limited information is available on the potential of oil palm frond residues in the management of goosegrass although these residues are usually left as mulch between oil palm trees for weed suppression and nutrient recycling purposes (Berger 2003). Thus, the present research was aimed at evaluating the potential of using the oil palm frond residues in combination with S-metolachlor for the control of herbicide-resistant biotypes of goosegrass.

\section{MATERIALS AND METHODS}

\section{GOOSEGRASS SEEDS}

Seeds of glufosinate, -glyphosate, -paraquat- and fluazifop-resistant biotypes of goosegrass were provided by Dr. Cha Thye San, Institute Marine Biotechnology, Universiti Malaysia Terengganu whereby these seeds were confirmed to have developed resistance to the respective herbicides from previous studies (Cha et al. 2014a, 2014b; Chuah et al. 2010). The herbicidesusceptible goosegrass seeds were collected from the roadside of Gong Badak in Kuala Terengganu, where no history of herbicide application has been recorded. Goosegrass seeds were scarified to remove the seed coat, using sand paper. The naked seeds were soaked in $0.2 \%$ potassium nitrate solution for $24 \mathrm{~h}$ to break the seed dormancy. The viability of the goosegrass seeds was tested to ensure the seeds had germination percentage higher than $90 \%$. The seeds were then rinsed with distilled water before use in the subsequent experiments.

\section{HERBICIDE}

The herbicides used in the study were S-metolachlor, fluazifop-b-butyl, glufosinate-ammonium, glyphosate isopropylamine and paraquat dichloride. These herbicides were purchased from KPT Peladang Sdn. Bhd, Kuala Terengganu.

\section{SOIL TYPES}

Three types of soil belonging to three different soil series were used in the present study. The 'Kangkung' soil series 
was collected from a coconut plantation at the Malaysian Agricultural Research and Development Institute (MARDI) Hilir Perak Station in Teluk Intan, Perak ( $3^{\circ} 53^{\prime} \mathrm{N}, 100^{\circ} 51^{\prime}$ E). The 'Rhu Tapai' soil series was collected from the Rhu Tapai of Agricultural Station in Setiu, Terengganu $\left(5^{\circ} 30^{\prime} \mathrm{N}, 102^{\circ} 58^{\prime} \mathrm{E}\right)$. The 'Bidor' soil series was collected from an ambarella (Spondias dulcis) farm located at Kampung Coldstream in Bidor, Perak ( $\left.4^{\circ} 02^{\prime} \mathrm{N}, 101^{\circ} 14^{\prime} \mathrm{E}\right)$. Soil samples were collected from the surface to $20 \mathrm{~cm}$ depth and transferred to a glasshouse from the respective locations. Each type of soil was sun-dried, ground and sieved to pass through a $2 \mathrm{~mm}$ screen. The Kangkung and Rhu Tapai soil samples were used for the glasshouse experiments.

\section{SOIL ANALYSIS}

The texture of each soil type was determined using the textural triangle (Anderson \& Ingram 1993). The soil pH was determined by placing a glass electrode with a $\mathrm{pH}$ meter (HI 3220) in a 1:1 mixture ratio of soil and deionized water (Singh \& Ratnasingham 1977).

The soil cation exchange capacity (CEC) was determined using the ammonium acetate method at $\mathrm{pH} 7.00$ (Chapman 1965). The soil was mixed with an excess amount of $1 \mathrm{M}$ ammonium acetate $\left(\mathrm{NH}_{4} \mathrm{OAc}\right)$ to cause an exchange of cations available in the soil. The amount of exchangeable ammonium was determined by distillation and titration using the Automatic Distillation Unit (VELP Scientifica UDK 149).

The soil organic carbon was determined using the Walkley-Black chromic acid and wet oxidation method (McLeod 1973). About $1 \mathrm{~N}$ of $\mathrm{K}_{2} \mathrm{Cr}_{2} \mathrm{O}_{7}$ solution was used to oxidize the oxidizable matter in the soil. The reaction was assisted by the heat generated from the 2:1 ratio mixture of $\mathrm{H}_{2} \mathrm{SO}_{4}$ and dichromate. The excess dichromate was titrated with ferrous sulphate and this titre was used to indicate the amount of carbon present in the soil sample.

The total bacterial count was determined using the standard spread-plate method (Seeley \& Vandemark 1981). One $g$ of the soil sample (dry weight equivalent) in $10 \mathrm{~mL}$ of sterile water was used to prepare a soil suspension ( $1 \mathrm{~g}$ in $10 \mathrm{~mL}$ sterile water). The soil suspension was then diluted serially (ten-fold) for estimation of the total bacterial count by the standard spread-plate dilution. Nutrient agar (NA) containing $0.015 \%(\mathrm{w} / \mathrm{v})$ nystatin was used for bacterial isolation and the data was expressed as colony forming units (CFU) per gram of dry soil.

\section{GLASSHOUSE EXPERIMENTS}

A preliminary test was conducted and it showed that the best combination of S-metolachlor (S-meto)-treated oil palm frond mulch (OPF) at a ratio of 40:60, provided synergistic action ( Lim 2015). This combination was therefore further examined in the experiment. S-metolachlor was applied at a suboptimal rate when combined with the oil palm frond mulch (compared to the recommended rate of S-metolachor@150 g ai ha-1).
A total of 20 glufosinate-resistant goosegrass seeds were sown evenly onto $75 \mathrm{~g}$ of the Kangkung or Rhu Tapai soil samples contained in plastic cups with holes at the bottom for drainage. On the day after sowing, the S-metolachlor -treated oil palm frond mulch was applied evenly on the soil surface at the following rates: $8.0 \mathrm{~g}$ ai ha $\mathrm{h}^{-1} \mathrm{~S}$-meto $+1.0 \mathrm{tha}^{-1} \mathrm{OPF}, 12.0 \mathrm{~g}^{2}$ ha $\mathrm{ha}^{-1} \mathrm{~S}-$ meto $+1.5 \mathrm{t} \mathrm{ha}^{-1} \mathrm{OPF}$, $16.0 \mathrm{~g}$ ai ha ${ }^{-1} \mathrm{~S}$-meto $+2.0 \mathrm{t} \mathrm{ha}^{-1}$ OPF under glasshouse conditions. The glasshouse conditions were maintained at relative humidity of $85 \%$, temperature $35-38^{\circ} \mathrm{C}$, a $12 \mathrm{~h}$ photoperiod and light intensity @ 800-1000 $\mu \mathrm{mol} \mathrm{m}^{-2} \mathrm{~s}^{-1}$. The experiment was repeated using seeds of glyphosate,fluazifop,-and paraquat-resistant biotypes of goosegrass. A complete randomized design with five replications was used. The goosegrass seedling emergence was counted while shoot fresh weight was determined 30 days after treatment. Seedlings were considered emerged when the shoot length was $>2 \mathrm{~mm}$. All data was expressed as percentages of the control.

\section{FIELD EXPERIMENTS}

The experiment was initiated from 11th November 2014 to 10th February 2015 at an ambarella orchard located at Kampung Coldstream in Bidor, Perak (402'N, $\left.101^{\circ} 14^{\prime} \mathrm{E}\right)$. The trees were planted in September 2012 at a planting distance of $1.5 \times 1.5 \mathrm{~m}$ and $2.0 \mathrm{~m}$ between rows. This area was $80 \%$ infested with the glyphosate-resistant biotype of goosegrass (Lim 2015). The experimental area consisted of 3 rows of the ambarella trees ( $15 \mathrm{~m}$ length $\times 3 \mathrm{~m}$ width), corresponding to 60 ambarella trees in an area of $45 \mathrm{~m}^{2}$. Meteorological data at the experimental site is shown in Table 1.

Plots measuring $0.8 \mathrm{~m}^{2}$ circular area with $1 \mathrm{~m}$ diameter were established under the canopy of the ambarella trees. The experimental areas were sprayed with a combination of glyphosate and clethodim at their respective recommended rates to eliminate emerging weedy plants at the tree base. Two weeks after herbicide application, the areas were cleared manually by hand weeding and flattened while weedy plants growing in between rows were controlled using a weed cutter before the treatments were applied at the areas below ambarella trees. A total of five treatments including the untreated plots were arranged in a randomized completed block design (RCBD) with three replications as follows:(T5) control: where the plots were not sprayed, (T3) chemical control: where the pre-emergence application

TABLE 1. Meteorological data at the experimental site from November 2014 to Jan 2015

\begin{tabular}{lccc}
\hline & Nov. & Dis. & Jan. \\
& 2014 & 2014 & 2015 \\
\hline Average monthly rainfall (mm) & 14.5 & 3.2 & 5.8 \\
Minimum temperature (C) & 22.8 & 22.9 & 21.6 \\
Maximum temperature (C) & 32.7 & 31.7 & 33.4 \\
Average temperature (C) & 27.8 & 27.3 & 27.5 \\
No. of rainy days (Day) & 22 & 23 & 16 \\
Highest 24 h rainfall (mm) & 111.2 & 32.0 & 34.2 \\
\hline
\end{tabular}


of S-metolachlor at a rate of $32 \mathrm{~g}$ ai ha ${ }^{-1}$ was carried out using a compression sprayer with a flat-fan nozzle, delivering a spraying volume of $450 \mathrm{~L} \mathrm{ha}^{-1}$ at $200 \mathrm{kPa}$, (T4): pre-emergence application of oil palm frond residue (OPF) as mulch at $4 \mathrm{tha}^{-1}$, (T1):pre-emergence application of S-metolachlor-treated OPF residue mulch at the rate of $16 \mathrm{~g}$ ai ha ${ }^{-1} \mathrm{~S}$-metolachlor mixed with $2 \mathrm{t}$ $\mathrm{ha}^{-1}$ OPF mulch and (T2): pre-emergence application of S-metolachlor-treated OPF mulch at a rate of $32 \mathrm{~g}$ ai ha $\mathrm{h}^{-1}$ $\mathrm{S}-$ metolachlor and $4 \mathrm{tha}^{-1}$ OPF mulch. For T1, T2 and T4 treatments, water was applied using a compression sprayer to deliver $470 \mathrm{~mL}$ of water per tree onto the soil surface of $0.8 \mathrm{~m}^{2}$ circular areas (before the application of the mulch).

Weed density and dry weight of goosegrass were determined at two months after each treatment by placing two quadrats $(0.25 \times 0.25 \mathrm{~m})$ in each plot. The weed samples were washed with tap water and counted to obtain weed density. The dry weight was determined after the weed samples were dried in the glasshouse for three weeks. All treatments were applied at the circular areas from the base of the ambarella tree.

\section{STATISTICAL ANALYSIS}

The data of glasshouse experiments were tested for the normality and homogeneity of variance before being subjected to the two-way analysis of variance, ANOVA (SPSS version 16 for Windows, SPSS Inc., 233 South Wacker Dr., Chicago, IL 60606). The arcsine square root and log transformations were performed on percentage data of emergence and shoot fresh weight for the glyphosateresistant biotypes, respectively. Then the data were subjected to the Tukey's test for comparison of means at the $5 \%$ level of significance. The $\mathrm{ED}_{50}$ values were estimated from the graphs plotted.

The data of the field experiments were subjected to the one-way analysis of variance (ANOVA). Since the block factor was not significantly different, data were pooled and combined. The data were checked for homogeneity of the variance test before being subjected to the oneway ANOVA. Log transformation was performed on plant density and dry weight data before being subjected to the one-way ANOVA. Tukey's test was carried out to compare means of treatments at the $5 \%$ level of significance.

\section{RESULTS}

PHYTOTOXIC EFFECTS OF S-METOLACHLOR-TREATED OIL PALM FROND RESIDUE TO HERBICIDE-RESISTANT BIOTYPES OF GOOSEGRASS IN DIFFERENT SOIL TYPES

The soil analysis showed that the Kangkung series is categorized as silty loam soil (21.8\% clay, $52.6 \%$ silt and $25.6 \%$ sand), while the Rhu Tapai series is classified as sandy loam soil (3.2\% clay, $30.0 \%$ silt and $66.8 \%$ sand). The value of the cation exchange capacity (C.E.C) was two-fold higher in the Kangkung series compared to that in the Rhu Tapai series, while the total bacterial count of the Kangkung series was two times lower than that of the Rhu Tapai series. The soil $\mathrm{pH}$ of the Kangkung series was 4.0 which are more acidic than the soil $\mathrm{pH}$ of 5.2 of the Rhu Tapai series. Besides, the respective organic carbon levels of the Kangkung and Rhu Tapai series were 1.6 and 2.7\%. The analysis showed that the soil samples collected from the ambarella farm were loamy soil, which consisted of $4.3 \%$ clay, $16.6 \%$ silt and $76.1 \%$ sand. The other properties such as $3.2 \%$ organic carbon, $5.5 \mathrm{meq}^{-1}$ C.E.C. and $\mathrm{pH}$ 6.0 were almost similar to those of Rhu Tapai soil series, except for the bacterial content $\left(3.4 \times 10^{6} \mathrm{CFU} \mathrm{g}^{-1}\right)$ which was 390 fold higher than that in the Rhu Tapai soil series (Table 2).

The S-metolachlor-treated oil palm frond mulch as rated-by-soil-series interaction was significant in glufosinate,-glyphosate,-and fluazifop-resistant biotypes of goosegrass (Figures $1 \& 2$ ). In general, all the resistant biotypes of goosegrass exhibited higher inhibitory effects when treated with S-metolachlor-treated oil palm frond mulch in the Rhu Tapai soil series compared to those exhibited by the plants in the Kangkung soil series. The $\mathrm{ED}_{50}$ values of the seedling emergence of glyphosate,glufosinate-or fluazifop-resistant biotypes of goosegrass in the Kangkung series ranged from 13 to $15 \mathrm{~g}$ ai ha $\mathrm{ha}^{-1}$ S-metolachlor +1.6 to $1.9 \mathrm{t} \mathrm{ha}^{-1}$ oil palm frond mulch (Figure 1). Higher suppressive effects were seen in the Rhu Tapai series where lower $\mathrm{ED}_{50}$ values of only 9 to 11 $\mathrm{g}$ ai ha ${ }^{-1} \mathrm{~S}$-metolachlor +1.2 to $1.4 \mathrm{tha}^{-1}$ oil palm frond mulch were needed (Figure 1).

In the present study, the suppressive effect of S-metolachlor-treated oil palm frond mulch on the glufosinate-resistant biotype of goosegrass was extremely poor when grown in the Kangkung soil series (Figure 2(a)).

TABLE 2. Physico-chemical characteristics, texture and microbial analyses of the Kangkung and Rhu Tapai soil series

\begin{tabular}{lccc}
\hline Parameter & Kangkung series & Rhu Tapai series & Bidor series \\
\hline Soil texture & Silt loam & Sandy loam & Loamy sand \\
Clay, \% & 21.8 & 3.2 & 4.3 \\
Silt, \% & 52.6 & 30.0 & 16.6 \\
Sand,\% & 25.6 & 66.8 & 76.1 \\
Organic carbon, \% & 1.6 & 2.7 & 3.2 \\
Cation exchange capacity, $\mathrm{meq}^{\mathrm{a}} \mathbf{1 0 0 ~ g}^{-1}$ & 10.3 & 5.2 & 5.5 \\
pH & 4.0 & 5.5 & 6.0 \\
Total bacteria count, CFU g-1 & $4.6 \times 10^{3}$ & $8.7 \times 10^{3}$ & $3.4 \times 10^{6}$ \\
\hline
\end{tabular}

a Abbreviations: meq, milliequivalents; CFU, colony forming units 


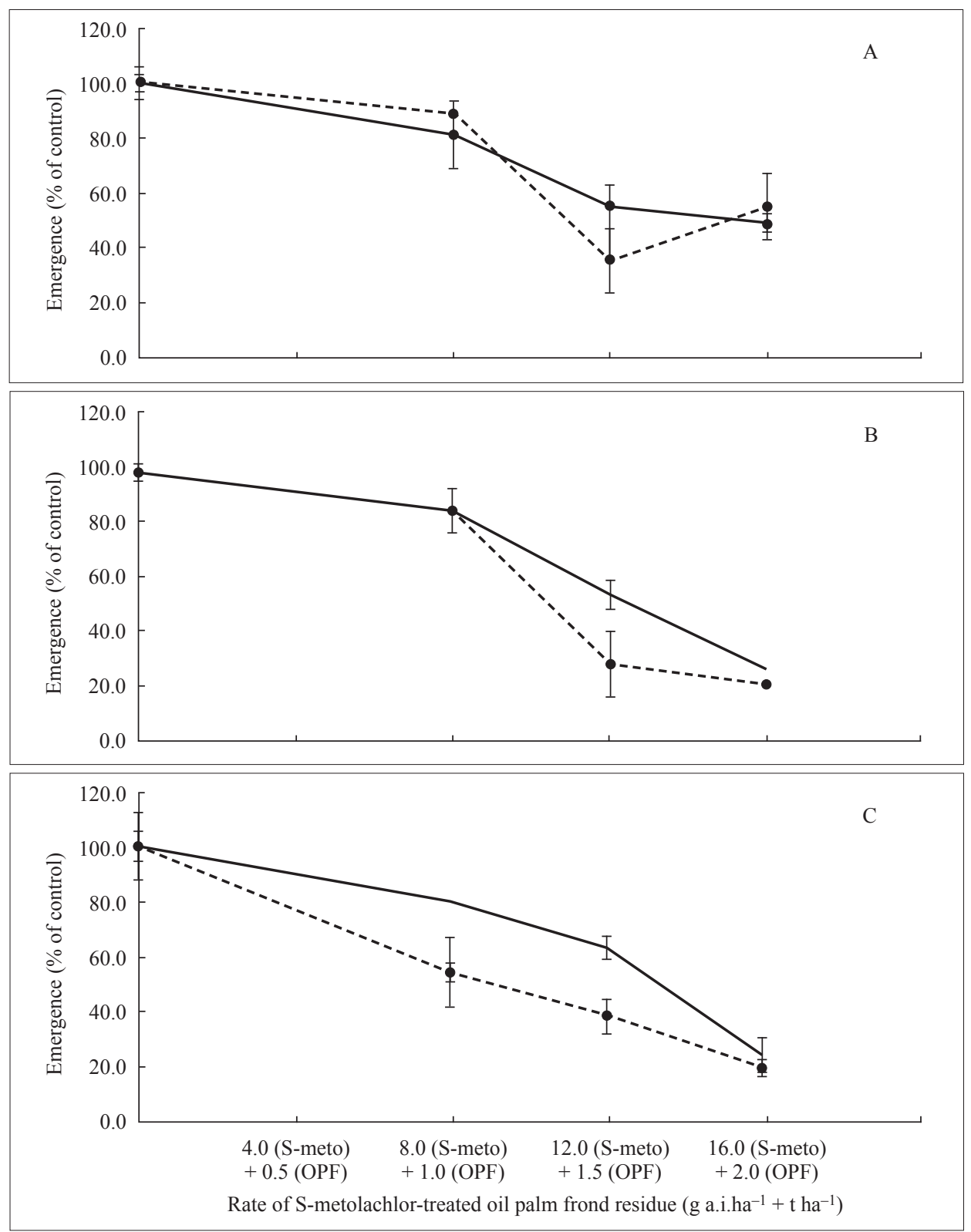

FIGURE 1. Pre-emergence application of S- metolachlor (S-meto) - treated oil palm frond mulch (OPF) on the seedling emergence of glufosinate-(A), glyphosate-(B), and fluazifop-(C) - resistant biotypes of goosegrass in the kangkung (一) and Rhu Tapai (‥) soil series Vertical bars represent standard deviation (SD) of the mean

This finding suggested that the S-metolachlor may have been applied frequently in the previous years before the glufosinate-resistant biotypes of goosegrass seeds were collected from the vegetable farms. As a consequence, the glufosinate-resistant biotypes may have developed resistance to S-metolachlor. The rate required to provide $\mathrm{ED}_{50}$ of the seedling growth of this goosegrass biotype could not be achieved even when the plants were subjected to the highest rate of S-metolachlor-treated oil palm frond mulch. Meanwhile the glyphosate -and fluazifop-resistant biotypes of goosegrass (Figure 2(b) and 2(c)) required about 12-14 g ai ha ${ }^{-1}$ S-metolachlor $+1.5-1.7 \mathrm{t} \mathrm{ha}^{-1}$ oil palm frond residue to provide the same level of inhibition. When tested on the Rhu Tapai soil series, the $\mathrm{ED}_{50}$ of the glufosinate-resistant biotype of goosegrass was achieved at $10 \mathrm{~g}$ ai ha ${ }^{-1} \mathrm{~S}-$ metolachlor $+1.25 \mathrm{tha}^{-1}$ oil palm frond residue while the glyphosate -and fluazifop-resistant biotypes of goosegrass required 6-7 $\mathrm{g}$ ai ha ${ }^{-1} \mathrm{~S}$-metolachlor $+0.8-0.9 \mathrm{t} \mathrm{ha}^{-1}$ oil palm frond residue to provide the same suppression.

Since no S-metolachlor-treated oil palm frond mulch rate-by-soil-series interaction was observed in the seedling emergence (Figure 3) and growth (Figure 4) of the paraquat-resistant biotype of goosegrass, data were pooled together and the main effects presented. It was noted that $16 \mathrm{~g}$ ai ha ${ }^{-1} \mathrm{~S}$-metolachlor $+2.0 \mathrm{tha}^{-1}$ oil palm frond mulch gave strong inhibition, with goosegrass seedling emergence and shoot fresh weight being reduced approximately by $80-85 \%$ on the average across the soil series. In comparison, no significant difference was 

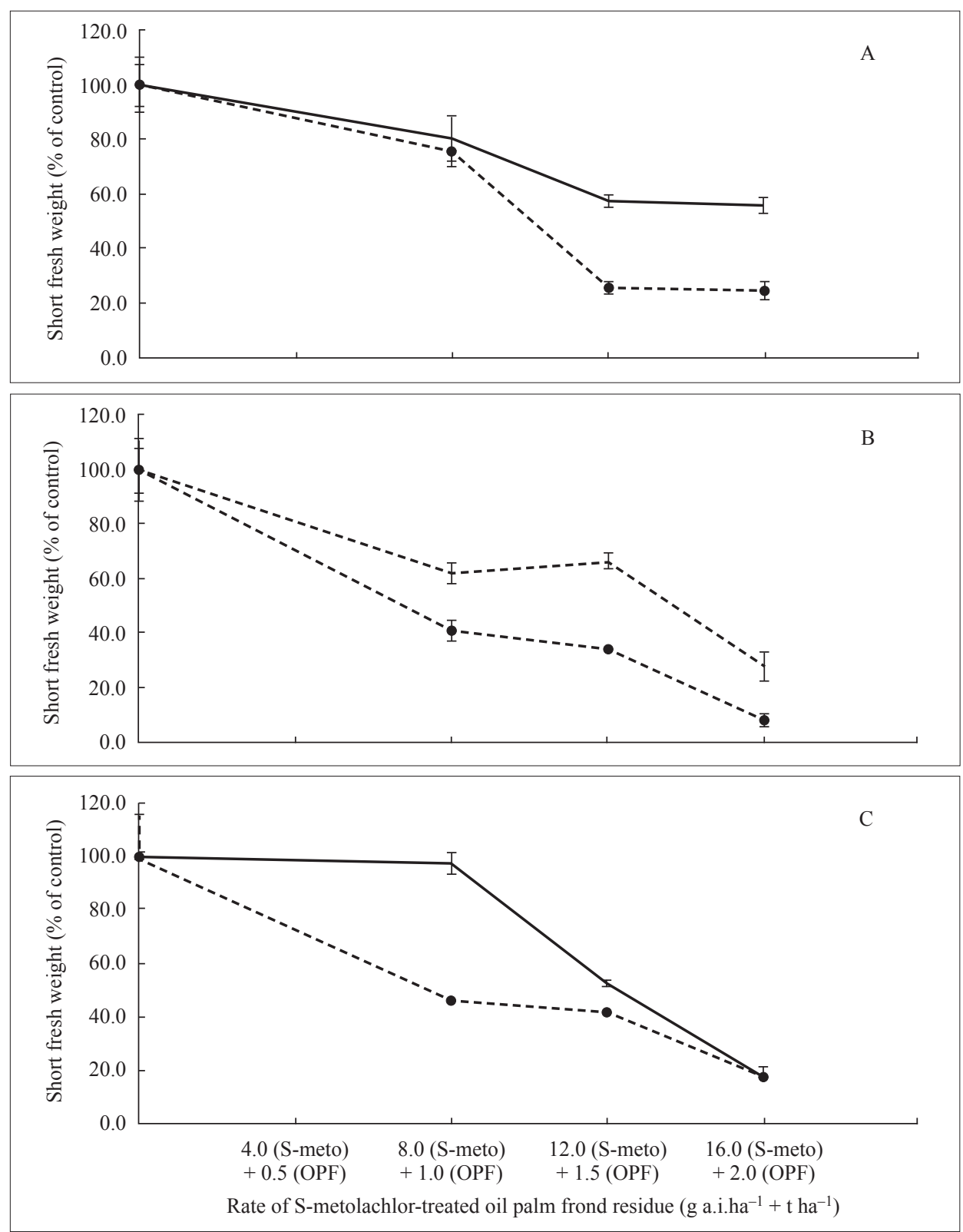

FIGURE 2. Pre-emergence application of S- metolachlor (S-meto) - treated oil palm frond mulch (OPF) on the shoot fresh weight of glufosinate-(A), glyphosate-(B) and fluazifop-(C) resistant biotypes of goosegrass in the kangkung (-) and Rhu Tapai (‥) soil series Vertical bars represent standard deviation (SD) of the mean

observed in shoot fresh weight of goosegrass $(60-65 \%$ of non-treated plants) when subjected to $8 \mathrm{~g}$ ai ha ${ }^{-1}$ S-metolachlor $+1.0 \mathrm{t} \mathrm{ha}^{-1}$ oil palm frond mulch and $12 \mathrm{~g}$ ai ha ${ }^{-1} \mathrm{~S}-$ metolachlor $+1.5 \mathrm{t} \mathrm{ha}^{-1}$ oil palm frond mulch although $12 \mathrm{~g}$ ai ha ${ }^{-1} \mathrm{~S}$-metolachlor $+1.5 \mathrm{tha}^{-1}$ oil palm frond mulch treatment provided higher inhibition of gooesegrass seedling emergence (compared to $8 \mathrm{~g}$ ai ha ${ }^{-1} \mathrm{~S}$-metolachlor $+1.0 \mathrm{t} \mathrm{ha}^{-1}$ oil palm frond mulch treatment). For the average S-metolachlor-treated oil palm frond mulch rate, seedling emergence (Figure 3(b)) and shoot fresh weight (Figure 4(b)) of goosegrass sown in Rhu Tapai soil (15-35\% of the non-treated plants) were lower compared to those in Kangkung soil (45\% of the non-treated plants).
PHYTOTOXIC EFFECT OF S-METOLACHLOR-TREATED OIL PALM FROND RESIDUE TO GLYPHOSATE-RESISTANT BIOTYPES OF GOOSEGRASS IN THE FIELD

Research conducted under field conditions provides more practical information on the efficacy of weed management employing S-metolachlor-treated mulch. It is interesting to note that plots which received $32.0 \mathrm{~g}$ ai ha ${ }^{-1} \mathrm{~S}$-metolachlor $+4.0 \mathrm{t} \mathrm{ha}^{-1}$ oil palm frond residue treatments provided the highest suppressive effect on goosegrass emergence and growth. This was followed by a single application of S-metolachlor at $32.0 \mathrm{~g}$ ai ha ${ }^{-1}$ which had higher inhibition on goosegrass seedlings compared to that from the rate of $16.0 \mathrm{~g}$ ai ha $\mathrm{h}^{-1} \mathrm{~S}$-metolachlor $+2.0 \mathrm{t} \mathrm{ha}^{-1}$ oil palm frond residue. However, no significant difference was observed 


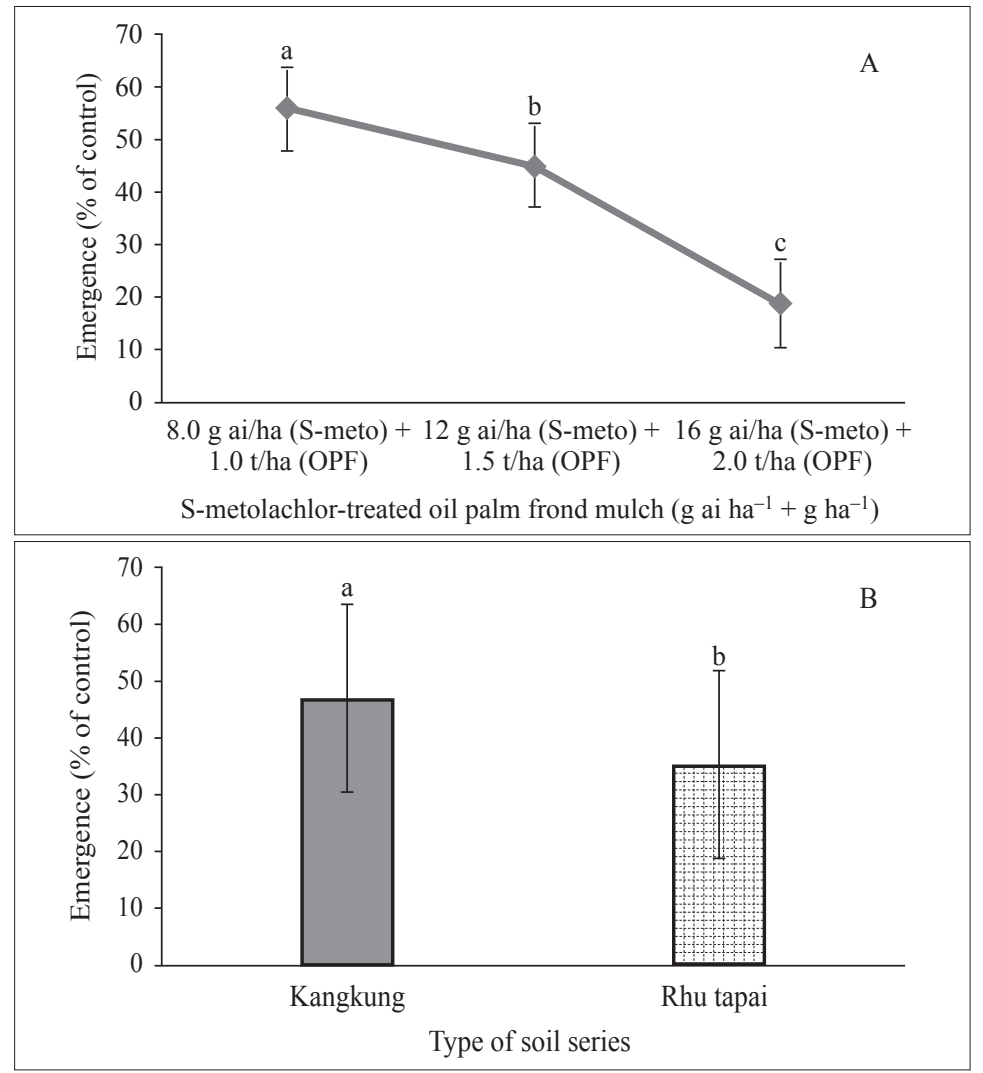

FIGURE 3. Main effects of S- metolachlor (S-meto) - treated oil palm frond (OPF) (A) mulches and soil series (B) on seedling emergence of paraquat- resistant biotypes of goosegrass one month after treatment

Vertical bars indicate the standard deviation (SD) of the mean. Means followed by similar alphabets indicate has no significant difference at $p \leq 0.05$ as determined by the Tukey test

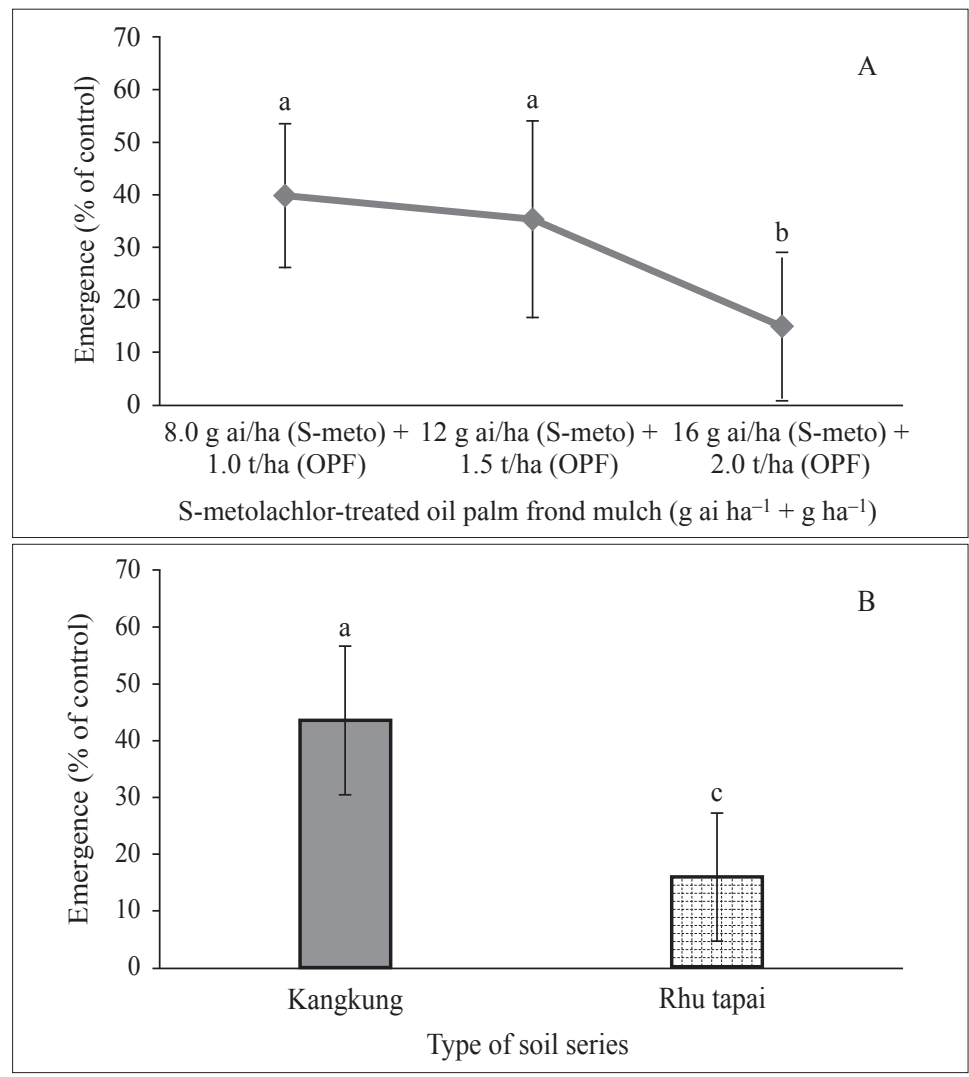

FIGURE 4. Main effects of S- metolachlor (S-meto) - treated oil palm frond (OPF) mulch (A) and soil series (B) on seedling growth of paraquat- resistant biotypes of goosegrass one month after treatment

Vertical bars indicate the standard deviation (SD) of the mean. Means followed by a similar alphabet indicates no significant difference at $p \leq 0.05$ as determined by the Tukey test 


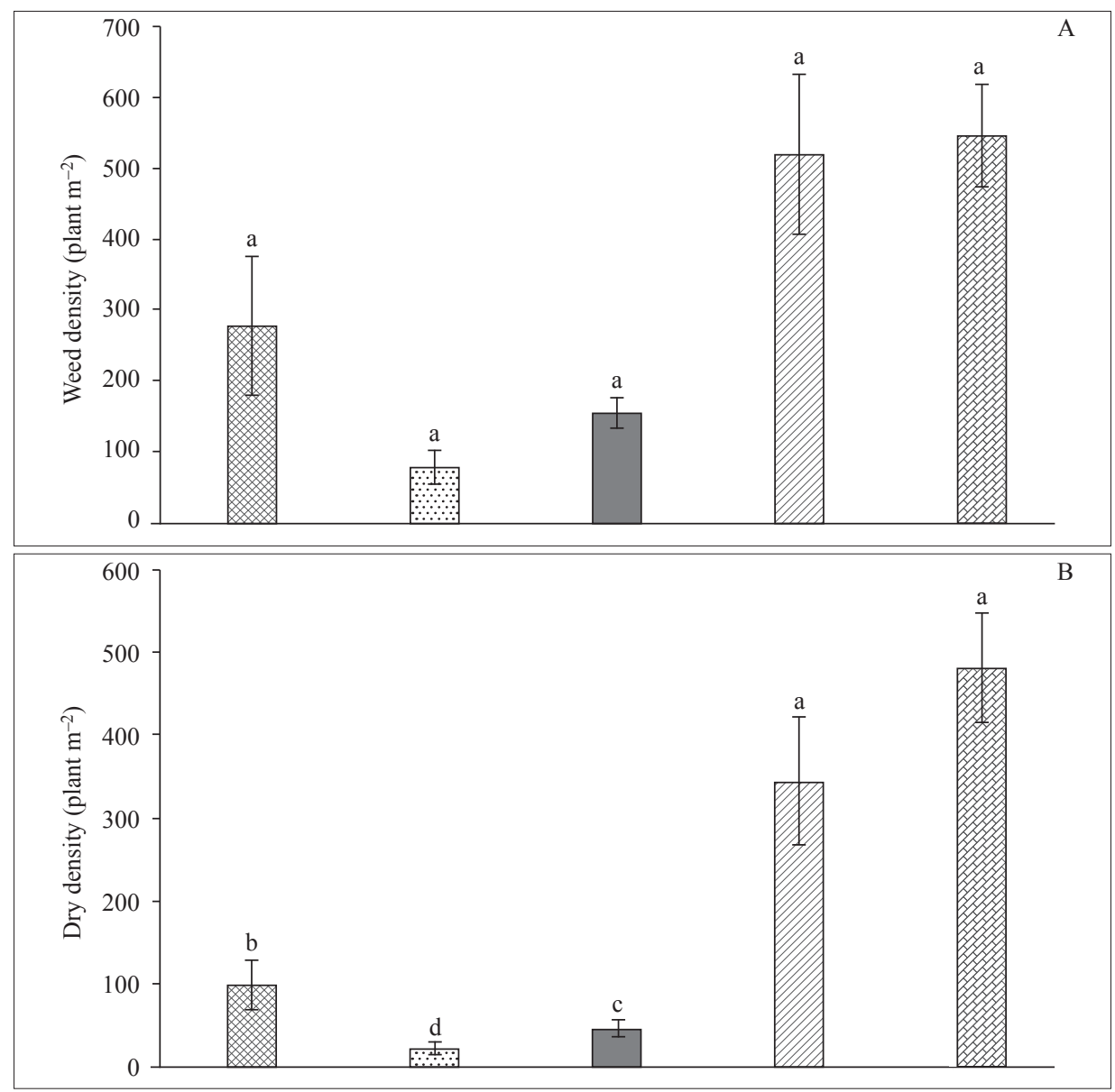

FIGURE 5. Pre-emergence application of S- metolachlor (S-meto) -treated oil palm frond (OPF) mulch, S-metolachlor and oil palm frond mulch on density (A) and dry weight (B) of glyphosate- resistant biotype of goosegrass at the ambarella farm two months after treatment

Vertical bars represent the standard deviation (SD) of the mean. Mean of treatments followed by a similar alphabet indicates no significant difference at $p \leq 0.05$ as determined by the Tukey test

between the untreated plot and plots subjected to oil palm frond mulch alone on goosegrass seedling emergence and biomass (Figure 5). Surprisingly, a combination rate of 16.0 $\mathrm{g}$ ai ha ${ }^{-1}+2.0 \mathrm{tha}^{-1} \mathrm{~S}$-metolachlor-treated oil palm frond mulch gave moderate control of the glyphosate-resistant biotypes of goosegrass although this treatment provided excellent control of the various types of herbicide-resistant biotypes of goosegrass under glasshouse conditions.

\section{DISCUSSION}

The Rhu Tapai soil series which has lower clay content and cation exchange capacity but higher $\mathrm{pH}$ value (Table 2) might have been responsible for more S-metolachlor molecules being made available for plant uptake, thus leading to a better suppression of goosegrass emergence and seedling growth. Westra et al. (2014) showed that, an Oleyney fine sandy loam soil with low clay content was able to retain $>90 \%$ of S-metolachlor in $7.5 \mathrm{~cm}$ of the soil profile. Soil $\mathrm{pH}$ plays an important role in herbicide sorption. The decrement of soil $\mathrm{pH}$ will cause an increment of herbicide sorption on the soil. This is due to the modification of the polar or ionic herbicide charges and/or the decrease of the variable charges of the soil constituents, favouring the adsorption of non-polar herbicides (Barriuso \& Calvet 1992; Grey et al. 1997). S-metolachlor has been reported to have $\mathrm{K}_{\mathrm{oc}} 74.4$ and $\mathrm{K}_{\mathrm{d}} 2.157 \mathrm{mLg}^{-1}$ when applied on sandy loam soil with $9.2 \%$ of clay and pH5.9. Further increase of the $\mathrm{pH}$ value will result in lower $\mathrm{K}_{\mathrm{oc}}$ and $\mathrm{K}_{\mathrm{d}}$ values which indicate a much lower sorption potential of S-metolachlor in the soil (Boger et al. 2000).

The reduced efficacy of S-metolachlor-treated oil palm frond residues in the field may be attributed to heavy rainfall after treatment (Table 1). Field experiments carried out in the present study were conducted from November 2014 to January 2015. High rainfall of 111 $\mathrm{mm}$ in November 2014 may have accelerated the leaching and run off potential of S-metolachlor when the herbicide molecules were slow-released from the oil palm frond residue mulch. This result is supported by previous findings where the shorter the interval between rainfall and the S-metolachlor application, the greater the herbicide is exported (Caron et al. 2012; Rector et al. 2003; Southwick et al. 2009). Furthermore, $2 \mathrm{t} \mathrm{ha}^{-1}$ oil palm frond residue mulch with a relatively fine-texture may not be sufficient to stay intact in the soil and can be easily washed away by 
heavy rainfall. A field experiment conducted by Somireddy (2011) found that hardwood mulch of relatively finetexture and smaller average particle size than pine nuggets was easily washed away by heavy rainfall. Billeaud and Zajicek (1989) showed that the mulch particle size would influence weed control, where the small-sized particles gave the poorest weed control during the rainy season. Another experiment conducted by Case and Mathers (2006) documented that there was higher suppression of weeds with the combination of herbicide and pine nuggets compared to that from the combination of hardwood mulch plus herbicides. It is likely that $16.0 \mathrm{~g}$ ai ha $\mathrm{ha}^{-1}+2.0 \mathrm{t} \mathrm{ha}^{-1}$ S-metolachlor-treated oil palm frond mulch hardly stayed intact at the soil surface for a long period of time during the wet season compared to that during the dry season, to suppress goosegrass growth and emergence.

A study on the degradation and leaching potential of metolachlor has shown that metolachlor molecules are relatively mobile in soil and categorized as the 'transient leacher' (Caracciolo et al. 2005). It was found that the matrix flow and preferential flow phenomena through soil macropores may help metolachlor to reach the deeper layers of the soil. Potential groundwater contamination may occur if the degradation phenomena at the soil surface do not significantly reduce their concentration (Caracciolo et al. 2005). Ng and Clegg (1997) have indicated that the variations of herbicide losses in the runoff components are largely influenced by the magnitude and occurrence time of rainfall during high intensity rainfall. For instance, 30-60 $\mathrm{mm}$ of rainfall occurring in two different days resulted in a massive loss of 3,000-8,000 mg of metolachlor. This may explain the lower efficacy of $32.0 \mathrm{~g}$ ai ha ${ }^{-1} \mathrm{~S}$-metolachlor application alone as compared to that of $32.0 \mathrm{~g}$ ai ha ${ }^{-1}+$ $4.0 \mathrm{t} \mathrm{ha}^{-1} \mathrm{~S}$-metolachlor-treated oil palm frond mulch in reducing goosegrass density and dry weight under field conditions in the present study.

Furthermore, the total bacterial count of soil samples collected from the amberella farm showed that the bacterial population is 740 -and 390 -folds higher than that in the Kangkung and Rhu Tapai soil series (Table 2). Hence, it is likely that reduced efficacy of $16.0 \mathrm{~g}$ ai ha $\mathrm{h}^{-1}+2.0$ $\mathrm{t} \mathrm{ha}^{-1} \mathrm{~S}$-metolachlor-treated oil palm frond mulch and a single application of S-metolachlor at the rate of 32.0 $\mathrm{g}$ ai $\mathrm{ha}^{-1}$ on the inhibition of goosegrass emergence and dry weight was due to the degradation of S-metolachlor by the soil microbes. The ability of soil microbes to degrade metolachlor has been proven by some researchers (Accinelli et al. 2001; Ma et al. 2006). For example, Candida xestobii and Bacillus simplex sampled from silty-clay soil were able to degrade 60 and $30 \%$ of the added metolachlor, respectively, after 4 and 5 days of growth in a medium (Munoz et al. 2011). Another study demonstrated that the soil microorganisms were able to mineralize metolachlor by using it as a source of carbon (Locke \& Harper 1991).

Some of the previous studies have indicated that the presence of soil organic matter may reduce the bioavailability of herbicides in the soil (Wu et al. 2011) through their adsorption to the organic carbon (Weishaar et al. 2003). Likewise, soil organic carbon also plays an important role in S-metolachlor adsorption. Previous studies have shown that degradation of herbicides in soils with high organic matter and soil moisture was faster than that in soils with low organic matter, due to the presence of higher levels of microbial activity in the high organic matter soils (Bolan \& Baskaran 1996; James et al. 2002). Bedmar et al. (2011) observed a 1.78 fold higher adsorption of S-metolachlor in the soil with $4.4 \%$ organic carbon compared to soil with $0.2 \%$ organic carbon. Based on the results of soil analysis, organic carbon in the soil samples collected from the ambarella field was about $3.2 \%$ while organic carbon of the Kangkung soil series used in the glasshouse study was $1.6 \%$. This may explain the reduced efficacy of $16.0 \mathrm{~g}$ ai ha ${ }^{-1}+2.0 \mathrm{tha}^{-1}$ S-metolachlor-treated oil palm frond mulch due to higher adsorption of S-metolachlor in soil at the ambarella fields, thereby reducing the bioavailability of S-metolachlor for goosegrass uptake.

Various factors have been proposed above to explain the reduced performance of $16.0 \mathrm{~g}$ ai ha $\mathrm{ha}^{-1}+2.0 \mathrm{tha}^{-1}$ S-metolachlor-treated oil palm frond mulch and $32.0 \mathrm{~g}$ ai $\mathrm{ha}^{-1}$ of S-metolachlor alone with the absence of oil palm frond mulch. Interestingly, when the application rate was doubled in the presence of oil palm frond residue, control of the glyphosate-resistant biotype of goosegrass improved. The treatment of $32.0 \mathrm{~g}$ ai ha ${ }^{-1} \mathrm{~S}$-metolachlor $+4.0 \mathrm{t} \mathrm{ha}^{-1}$ oil palm frond mulch performed better with high rainfall intensity, whereby $85-95 \%$ of the goosegrass density and dry weight was reduced compared to that at zero treatment. Apparently, the confounding factor in reducing the efficacy of this treatment in the presence of rainfall is negligible; in contrast, the rainfall appeared to increase the S-metolachlor bioavailability in the soil for goosegrass uptake. Somireddy (2011) also reported that after the application of trifluralin + isoxaben-treated pine nuggets at the experimental site, heavy rainfall caused more herbicides to be dislodged from the pine nuggets into the soil, thus improving weed suppression compared to that obtained at low rainfall intensity. On the other hand, Simmons and Derr (2007) have demonstrated that more pendimethalin was released from pendimethalin-treated pine bark after regular application of irrigation water. The researcher stated that the herbicide was highly available at the soil surface and could possibly increase weed control effectiveness. The application rate of $32.0 \mathrm{~g}$ ai ha $\mathrm{ha}^{-1}$ S-metolachlor $+4.0 \mathrm{t} \mathrm{ha}^{-1}$ oil palm frond combination may be able to stay intact in the soil longer without reduction of its efficacy on goosegrass control. Furthermore, the higher rate of oil palm frond residue of $4.0 \mathrm{t} \mathrm{ha}^{-1}$ may provide thicker soil cover and help reduce run off and leaching of S-metolachlor more effectively during the rainy season. Aforementioned previous studies have reported that a higher rate of crop residue suppressed weed emergence and growth more effectively through reduction of light transmittance (Teasdale \& Mohler 1993) and this has proven to be significantly effective against goosegrass because goosegrass germination is highly dependent on light (Chauhan \& Johnson 2008). 
A previous study conducted to compare the herbicide bioavailability in paper pulp and sawdust showed that the crop suffered greater injury when alachlor or chlorpropham was applied on the sawdust (46\% organic carbon), compared to that on the paper pulp (22\% organic carbon) as the planting medium (James 2008). The reason could be that sawdust is usually in a raw, undecomposed state and is comprised mainly of relatively big particles of cellulose with very low surface area to mass ratio whereas paper pulp is much more degraded as the cellulose has been broken down during the chemical processes of paper making. Paper pulp with $22 \%$ organic carbon as planting medium is believed to provide a longer binding site for herbicide adsorption and hence a higher tolerance level of the herbicide on the crop was observed. Similarly, in the present study, the oil palm frond residue with $52.28 \%$ organic carbon content (Sukiran et al. 2009) was found to enhance the S-metolachlor activity in the soil because the oil palm frond residue was in a raw, undecomposed state and comprised mostly of relatively big particles of cellulose even though the residue had been ground to powder form. As a result, the oil palm frond residue could not reduce the bioavailability of S-metolachlor in the soil, but most likely acted as a slow release carrier the S-metolachlor.

The application of $4.0 \mathrm{t} \mathrm{ha}^{-1}$ of oil palm frond mulch alone did not provide better control of goosegrass under field conditions although at the same rate it was able to provide more than $90 \%$ inhibition of goosegrass emergence under glasshouse conditions (Figure 4(a) and 4(b)). When compared to the untreated plot, the reduction of goosegrass density and dry weight was insignificant when treated with $4.0 \mathrm{t} \mathrm{ha}^{-1}$ of oil palm frond mulch under field conditions. The poor performance of the oil palm frond residue alone might be due to the presence of confounding factors such as rainfall (Somireddy 2011) and wind (Athy et al. 2006). Furthermore, the occurrence of rain droplets may have caused uneven distribution of the mulch. Some of the goosegrass plants might have escaped from being covered by mulch and this could have led to lower efficacy of the control (Buhler 1995; Chauhan et al. 2006). Chauhan and Abugho (2012) and Chauhan et al. (2012) have reported that, the use of crop residue alone as mulch will not provide a complete and long term control of weeds and therefore, alternative strategies by integrating herbicide into the residue has been suggested.

\section{CONCLUSION}

It can be concluded that the emergence and seedling growth of goosegrass plants were greatly suppressed when treated with S-metolachlor-treated oil palm frond mulch at $12 \mathrm{~g}$ ai h $\mathrm{h}^{-1} \mathrm{~S}$-meto $+1.5 \mathrm{t} \mathrm{ha}^{-1}$ oil palm frond residue (OPF), regardless of the biotype of goosegrass used, with the exception of the glufosinate-resistant biotypes of goosegrass in the Rhu Tapai soil series and those in the Kangkung soil series under glasshouse conditions. Field experiments in an ambarella farm further showed that $\mathrm{S}$-metolachlor-treated oil palm frond mulch at the rate of $32.0 \mathrm{~g}$ ai ha ${ }^{-1}$ S-meto $+4.0 \mathrm{t} \mathrm{ha}^{-1}$ OPF had the highest suppressive effects on glyphosate-resistant biotypes of goosegrass, compared to those caused by $16.0 \mathrm{~g}^{\mathrm{ai}} \mathrm{ha}^{-1}$ $\mathrm{S}$-meto $+2.0 \mathrm{t} \mathrm{ha}^{-1}$ OPF. By doubling the rate of the S-metolachlor-treated oil palm frond mulch to $32.0 \mathrm{~g}$ ai ha ${ }^{-1}$ $+4.0 \mathrm{t} \mathrm{ha}^{-1}$ better inhibition of goosegrass was obtained. Nevertheless, the rate of $16.0 \mathrm{~g}$ ai ha ${ }^{-1}$ S-meto $+2.0 \mathrm{t} \mathrm{ha}^{-1}$ OPF still gave good control of goosegrass with 66 and $87 \%$ reduction of weed density and biomass, respectively.

Further research is needed to determine the role of OPF when applied in combination with S-metolachlor. It is hypothesized that the OPF residue may act as a slow release carrier for S-metolachlor or the presence of various allelochemicals in the OPF may act synergistically with S-metolachlor in suppressing the goosegrass emergence and growth. This information is essential for the development of an alternative approach whereby less chemical inputs are used but more effective weed control is acieved in orchards, vegetable farms, nurseries of ornamental plants, potted plants and landscaped areas. Application of the S-metolachlor-treated oil palm frond residue at the canopy plot area of ornamental plants at landscaped areas and gardens is recommended as an alternative to hand weeding which is labour intensive and time consuming. Besides, allelochemicals present in the OPF residue is could possibly enhance the performance of S-metolachlor in combination with OPF and the discovery of allelochemicals in the OPF residue may help in the development of a novel and environmental-friendly natural herbicide obtained from transforming agricultural waste into wealth and creating a better environment for human society.

\section{REFERENCES}

Accinelli, C., Dinelli, G., Vicari, A. \& Catizone, P. 2001. Atrazine and metolachlor degradation in subsoil. Biology and Fertility of Soils 33: 495-500.

Anderson, J.M. \& Ingram, J.S. 1993. Tropical Soil Biology and Fertility: A Handbook of Methods. 2nd ed. Wallingford, CAB International, UK. pp. 93-94.

Athy, E.R., Keiffer, C.H. \& Stevens, M.H. 2006. Effect of mulch on seedlings and soil on a closed landfill. Restoration Ecology 14: 233-241.

Barriuso, E. \& Calvet, R. 1992. Soil type and herbicide adsorption. International Journal of Environmental and Analytical Chemistry 46: 117-128.

Batish, D.R., Kaur, M., Singh, H.P. \& Kohli, R.K. 2007. Phytotoxicity of a medicinal plant, Anisomeles indica, against Phalaris minor and its potential use as natural herbicide in wheat fields. Crop Protection 26: 948-952.

Bedmar, F., Daniel, P.E., Costa, J.L. \& Gimenez, D. 2011. Sorption of acetochlor, S-metolachlor, and atrazine in surface and subsurface soil horizons of Argentina. Environmental Toxicology and Chemistry 30: 1990-1996.

Bethke, R.K., Molin, W.T., Sprague, C. \& Penner, D. 2013. Evaluation of the interaction between glyphosate and glufosinate. Weed Science 61: 41-47.

Berger, K. 2003. Palm Oil. In Wiley Encyclopedia of Food Sciences and Nutrition. 2nd ed. Palm Oil Research Institute of Malaysia, Malaysia. pp. 4325-4331. 
Billeaud, L.A. \& Zajicek, J.M. 1989. Influence of mulches on weed control, soil $\mathrm{pH}$, soil nitrogen content, and growth of Ligustrum japonicum. Journal of Environmental Horticulture 7: 155-157.

Blaser, H.U. \& Spindler, F. 1997. Enantioselective catalysis for agrochemicals: The case history of the DUAL MAGNUM herbicide. Chimmia 51: 297-299.

Böger, P., Matthes, B. \& Schmalfuss, J. 2000. Towards the primary target of chloroacetamides-new findings pave the way. Pest Management Science 56: 497-508.

Bolan, N.S. \& Baskaran, S. 1996. Biodegradation of 2, 4-D herbicide as affected by its adsorption-desorption behavior and microbial activity of soils. Australian Journal of Soil Research 34: 1041-1053.

Buhler, D.D. 1995. Influence of tillage systems on weed population dynamics and management in corn and soybean in the central USA. Crop Science 35: 1247-1258.

Caracciolo, A.B., Giulianoa, G., Grennia, P., Guzzellab, L., Pozzonib, F., Bottonic, P., Favac, L., Crobec, A., Orru, M. \& Funaric, E. 2005. Degradation and leaching of the herbicides metolachlor and diuron: A case study in an area of Northern Italy. Environmental Pollution 134: 525-534.

Caron, E., Lafrance, P. \& Auclair, J.C. 2012. Temporal evolution of atrazine and metolachlor concentration exported in runoff and subsurface water with vegetated filter strips. Agronomy for Sustainable Development 32: 935-943.

Case, L.T. \& Mathers, H.M. 2006. Herbicide treated mulches for weed control in ornamentals. Journal of Environmental Horticulture 24: 84-90.

Cha, T.S., Najihah, M., Ismail, B.S. \& Chuah, T.S. 2014a. Molecular basis for resistance to ACCase inhibiting fluazifop in Eleusine indica from Malaysia. Pesticide Biochemistry and Physiology 111: 7-1.

Cha, T.S., Anne-Marie, K. \& Chuah, T.S. 2014b. Identification and characterization of RAPD-SCAR markers linked to glyphosate-susceptible and -resistant biotypes of Eleusine indica (L.) Gaertn. Molecular Biology Reports 41(2): 823-831.

Chapman, H.D. 1965. Cation-exchange capacity. In Methods of Soil Analysis Chemical and Microbiological Properties, edited by Black, C.A. Agronomy 9: 891-901.

Chauhan, B.S. \& Abugho, S.B. 2012. Interaction of rice residue and pre-herbicides on emergence and biomass of four weed species. Weed Technology 26: 627-632.

Chauhan, B.S. \& Johnson, D.E. 2008. Germination ecology of goosegrass (Eleusine indica): An important grass weed of rainfed rice. Weed Science 56: 699-706.

Chauhan, B.S., Singh, R.G. \& Mahajan, G. 2012. Ecology and management of weeds under conservation agriculture: A review. Crop Protection 38: 57-65.

Chauhan, B.S., Gill, G. \& Preston, C. 2006. Tillage system effects on weed ecology herbicide activity and persistence: A review. Australian Journal of Experimental Agriculture 46: $1557-1570$

Chuah, T.S. \& Lim, W.K. 2015. Assessment of phytotoxic potential of oil palm leaflet, rachis and frond extracts and powders on goosegrass (Eleusine indica (L.) Gaertn.) germination, emergence and seedling growth. Malaysian Applied Biology 44: 75-84.

Chuah, T.S., Low, V.L., Cha, T.S. \& Ismail, B.S. 2010. Initial report of glufosinate and paraquat multiple resistance that evolved in a biotype of goosegrass (Eleusine indica) in Malaysia. Weed Biology and Management 10: 229-233.

Chuah, T.S., Teh, H.H., Cha, T.S. \& Ismail, B.S. 2008. Antagonism of glufosinate ammonium activity caused by glyphosate in tank mixtures used for control of goosegrass (Eleusine indica Gaertn.). Plant Protection Quarterly 23: 116-119.

Chuah, T.S., Salmijah, S. \& Ismail, B.S. 2004a. Efficacy of tank-mix combinations of glyphosate and gramicides on the control of glyphosate-resistant and susceptible biotypes of goosegrass (Eleusine indica (L.) Gaertn.). Plant Protection Quarterly 19: 130-134.

Chuah, T.S., Salmijah, S., Teng, Y.T. \& Ismail, B.S. 2004b. Changes in seed bank size and dormancy characteristics of the glyphosate-resistant biotype of goosegrass (Eleusine indica (L.) Gaertn.). Weed Biology and Management 4: 114-121.

Clewis, S.B., Miller, D.K., Koger, C.H., Baughman, T.A., Price, A.J., Potterfield, D. \& Wilcut, J.W. 2008. Weed management and crop response with glyphosate, S-metolachlor, trifloxysulfuron, prometryn, and MSMA in glyphosate resistant cotton. Weed Technology 22: 160-167.

Dilipkumar, M., Mazira, C.M. \& Chuah, T.S. 2017. The potential use of oil palm frond mulch treated with Imazethapyr for weed control in Malaysian coconut plantation. Sains Malaysiana 46(8): 1171-1181.

Everman, W.J., Clewis, S.B., York, A.C. \& Wilcut, J.W. 2009. Weed control and yield with flumioxazin, fomesafen, and S-metolachlor systems for glufosinate-resistant cotton residual weed management. Weed Technology 23: 391-397.

Grey, T.L., Walker, R.H., Wehtje, G.R.H. \& Hancock, H.G. 1997. Sulfentrazone adsorption and mobility as affected by soil and $\mathrm{pH}$. Weed Science 45: 733-738.

Heap, I. 2017. The International Survey of Herbicide Resistant Weeds. www.weedscience.org. Accessed on 25 Sep 2017.

Holm, L.G., Plucknett, D.L., Pancho, J.V. \& Herberger, J.P. 1977. The World's Worst Weeds: Distribution and Biology. Honolulu, Hawaii: University Press of Hawaii.

Ismail, B.S., Chuah, T.S., Salmijah, S. \& Teng, Y.T. 2003. Effects of shade and watering frequency on growth and development of glyphosate-resistant and susceptible biotypes of goosegrass (Eleusine indica (L.) Gaertn.). Plant Protection Quarterly 18: 30-34.

Ismail, B.S., Chuah, T.S., Salmijah, S., Teng, Y.T. \& Schumacher, R.W. 2002. Germination and seedling emergence of the glyphosate-resistant and susceptible biotype of goosegrass (Eleusine indica (L.) Gaertn.). Weed Biology and Management 2: 177-185.

Jalaludin, A., Yu, Q. \& Powles, S.B. 2015. Multiple resistances across glufosinate, glyphosate, paraquat and ACCaseinhibiting herbicides in an Eleusine indica population. Weed Research 55: 82-89.

James, T.K. 2008. Characterizations of herbicide behavior in some innovative growing media. Ph.D thesis. Palmerston North, New Zealand: Massey University (Unpublished).

James, T.K., Holland, P.T., Rahman, A. \& Lu, Y.R. 2002. Degradation of the sulfonylurea herbicides chlorsulfuron and triasulfuron in high-organic matter volcanic soil. Weed Research 39: 137-147.

Lim, W.K. 2015. Phytotoxic effects of S-metolachlor in combination with oil palm frond mulches on herbicideresistant biotypes of goosegrass. Master thesis. Terengganu, Malaysia: University of Malaysia Terengganu (Unpublished).

Locke, M.A. \& Harper, S.S. 1991. Metribuzin degradation in soil: II-Effects of tillage. Pesticide Science 31: 239-247.

Ma, Y., Liu, W.P. \& Wen, Y.Z. 2006. Enantio selective degradation of Rac-metolachlor and S metolachlor in soil. Pedosphere 16: 489-494. 
Ma, X.Y., Wu, H.W., Jiang, W.L., Ma, Y.J. \& Ma, Y. 2015. Goosegrass (Eluisine indica) density effects on cotton (Gossypium hirsutum). Journal of Integrative Agriculture 14: $1778-1785$

Mcleod, S. 1973. Studies on wet oxidation procedures for the determination of organic carbon in soils. In Notes on Soil Techniques. CSIRO Division of Soils. pp. 73-79.

Munoz, A., Koskinen, W.C., Cox, L. \& Sadowsky, M.J. 2011. Biodegradation and mineralization of metolachlor and alachlor by Candida xestobii. Journal of Agricultural and Food Chemistry 59: 619-627.

Ng, H.Y.F. \& Clegg, S.B. 1997. Atrazine and metolachlor losses in runoff events from an agricultural watershed: The importance of runoff components. Science of the Total Environment 193: 215-228.

O'connel, P.J., Harms, C.T. \& Allen, J.R.F. 1998. Metolachlor, S-metolachlor and their within sustainable weedmanagement role. Crop Protection 17: 207-212.

Odero, D.C., Rice, R. \& Baucum, L. 2013. Biology and Control of Goosegrass in Sugarcane, SS-AGR-367. University of Florida Institute of Food and Agricultural Sciences. http:// edis.ifas.ufl.edu/sc096. Accessed on 10 May 2015.

Rector, R.J., Regehr, D.L., Barnes, P.L. \& Loughin, T.M. 2003. Atrazine, S-metolachlor, and isoxaflutole loss in runoff as affected by rainfall and management. Weed Science 51: 810-816.

Rizzardi, M.A. \& Wandscheer, A.C.D. 2014. Interference of Sorghum sudanense and Eleucine indica in the soybean and corn cultivation. Planta Daninha 32: 19-30.

Seeley, H.W. \& Vandenmark, P.J. 1981. Microbes in Action: A Laboratory Manual of Microbiology. 3rd ed. U.S.A.: W.H. Freeman and Company. p. 350.

Simmons, L.D. \& Derr, J.F. 2007. Pendimethalin movement through pine bark compared to field soil. Weed Technology 21: 873-876.

Singh, M.M. \& Ratnasingham, K. 1977. Manual of Laboratory Methods of Chemical Soil Analysis. Ampang: Rubber Research Institute of Malaysia.

Somireddy, U.R. 2011. Effect of herbicide-organic mulch combinations on weed control and herbicide persistence. Ph.D thesis. Columbus, United States: The Ohio State University (Unpublished)

Southwick, L.M., Appelboom, T.W. \& Fouss, J.L. 2009. Runoff and leaching of metolachlor from Mississippi River alluvial soil during seasons of average and below average rainfall. Journal of Agricultural and Food Chemistry 57: $1413-1420$

Stecker, L. 2010. W116 Goosegrass. The University of Tennessee Agricultural Extension Service, 06-0089. http://trace.tennessee.edu/utk agexcrop/109. Accessed on 2 May 2013

Sukiran, M.A., Chin, C.M. \& Bakar, N.K.A. 2009. Bio-oil from pyrolysis of oil palm empty fruit bunches. American Journal of Applied Sciences 6: 869-875.

Teasdale, J.R. \& Mohler, C.L. 1993. Light transmittance, soil temperature, and soil moisture under residue of hairy vetch and rye. Agronomy Journal 85: 673-680.

Teasdale, J.R. \& Mohler, C.L. 2000. The quantitate relationship between weed emergence and the physical properties of mulches. Weed Science 48: 385-392.

Weishaar, J.L., Aiken, G.R., Bergamaschi, B.A., Fram, M.S., Fujii, R. \& Mopper, K. 2003. Evaluation of specified ultraviolet absorbance as an indicator of the chemical composition reactivity of dissolved organic carbon. Environmental Science \& Technology 37: 4702-4708.

Westra, E.P., Shaner, D.L., Westra, P.H. \& Chapman, P.L. 2014. Dissipation and leaching of Pyroxasulfone and S-Metolachlor. Weed Technology 28: 72-81.

Wiecko, G. 2000. Sequential herbicide treatments for goosegrass (Eleusine indica) control in bermudagrass (Cynodon dactylon) turf. Weed Technology 14: 686-691.

Wilen, C.A., Schuch, U.K. \& Elmore, C.L. 1999. Mulches and subirrigation control weeds in container production. Journal of Environmental Horticulture 17: 174-180.

Wu, X.M., Li, M., Long, Y.H., Liu, R.X., Yu, Y.L., Fang, H. \& Li, S.N. 2011. Effects of adsorption on degradation and bioavailability of metolachlor in soil. Journal of Soil Science and Plant Nutrition 11: 83-97.

Chuah Tse Seng* \& Lim Win Kent

School of Food Science and Technology

Laboratory of Agri-food Pest and Disease Management

University of Malaysia Terengganu

21030 Kuala Terengganu, Terengganu Darul Iman

Malaysia

Ismail B.S

School of Environmental and Natural Resource Sciences

Faculty of Science and Technology

Universiti Kebangsaan Malaysia

43600 UKM Bangi, Selangor Darul Ehsan

Malaysia

*Corresponding author; email: chuahts@umt.edu.my

Received: 28 March 2017

Accepted: 24 October 2017 